J. Dairy Sci. 95:2531-2539

http://dx.doi.org/10.3168/jds.2011-5053

(C) American Dairy Science Association ${ }^{\circledR}, 2012$.

\title{
Blocking opioid receptors alters short-term feed intake and oro-sensorial preferences in weaned calves
}

\author{
C. Montoro, ${ }^{*}$ I. R. Ipharraguerre, $†$ and A. Bach* $\ddagger^{1}$ \\ *Department of Ruminant Production, IRTA (Institut de Recerca i Tecnologia Agroalimentàries), 08140, Caldes de Montbui, Spain \\ †Lucta S.A., 08170, Montornès del Vallès, Spain \\ łICREA (Institució Catalana de Recerca i Estudis Avançats), 08010 Barcelona, Spain
}

\section{ABSTRACT}

Opioid peptides may participate in the control of feed intake through mechanisms involving pleasure reward linked to consumption of palatable feed. The objective of this study was to determine whether blocking opioid receptors might void oro-sensorial preferences of calves, and affect circulating glucose, insulin, and anorexigenic hormones in fasted and fed calves. Two experiments involved 32 Holstein calves [body weight $(\mathrm{BW})=86.5 \pm 1.73 \mathrm{~kg}$, age $=72 \pm 0.6 \mathrm{~d}]$. In experiment 1, all calves received an ad libitum choice of the same feed either unflavored or flavored with a sweetener (Luctarom SFS-R, Lucta, Montornès del Vallès, Spain). Feed consumption was recorded every $2 \mathrm{~h}$ from 0800 to $1400 \mathrm{~h}$ for 3 consecutive days to verify the establishment of an oro-sensorial preference for sweet feed (SF). The SF was preferred over the control feed $(\mathrm{CF})$ at all recorded times. In experiment 2, calves were subjected to a $2 \times 2$ factorial design to study the interaction between opioid activity and metabolic state. Half of the calves were fasted for $14 \mathrm{~h}$ (FAS), whereas the other half remained well fed (FED). Within each of these groups, at feeding time $(0800 \mathrm{~h})$, half of the calves received an i.v. injection of naloxone (NAL, an opioid receptor antagonist; $1 \mathrm{mg} / \mathrm{kg}$ of $\mathrm{BW}$ ) and the other half was injected with saline solution (SAL; $0.9 \%$ $\mathrm{NaCl}$ ). Therefore, treatments were FED-NAL, FEDSAL, FAS-NAL, and FAS-SAL. Blood samples were taken at $-10,20,180$, and 240 min relative to NAL or SAL injections. As expected, cumulative consumption of starter feed was greater in FAS than in FED calves. Total feed consumption $2 \mathrm{~h}$ after feeding was lower in NAL than in SAL calves. Calves in the FAS group did not discern between $\mathrm{CF}$ and $\mathrm{SF}$ during the first $4 \mathrm{~h}$ after feed offer. Preference for SF was greater in SAL than in NAL calves. Calves in the FED-SAL treatment

Received October 16, 2011.

Accepted January 11, 2012.

${ }^{1}$ Corresponding author: alex.bach@irta.es preferred $\mathrm{SF}$ at 2 and $6 \mathrm{~h}$ after feed offer and tended to prefer SF at $4 \mathrm{~h}$ after feeding. However, FED-NAL calves did not discern between $\mathrm{SF}$ and $\mathrm{CF}$ during the first $4 \mathrm{~h}$ after feeding and tended to prefer SF only after $6 \mathrm{~h}$ from feeding. Plasma glucose, insulin, and cholecystokinin concentrations were greater in FED than in FAS calves. Injection of naloxone decreased plasma glucagon-like peptide-1 (GLP-1) in NAL calves. Blocking opioid receptors reduced intake the first $2 \mathrm{~h}$ after naloxone injection in FED calves, altered oro-sensorial preferences, and reduced plasma GLP-1 concentration. In conclusion, the opioid peptide system may control short-term feed intake by modulating the oro-sensorial response triggered by feed consumption, especially when calves are fed ad libitum.

Key words: calf, intake, naloxone, preference

\section{INTRODUCTION}

Mounting evidence demonstrating that high planes of nutrition are associated with future improvements in animal performance (Bach, in press) has emphasized the relevance of either feeding large volumes of milk to calves (Khan et al., 2007) or fostering increases in solid feed intake (Castells et al., 2012), or both (Roth et al., 2009). The neuroendocrine control of feed intake and energy balance is a complex process controlled by many overlapping, integrated pathways (Sartin et al., 2011). In mammals, the hypothalamus plays a central role in this regard (Clarke, 2001; Wagner et al., 2004), and opioid receptors have been found in the hypothalamus (Hökfelt et al., 1977) as well as in limbic structures involved in the control of food reward and eating behavior (Berridge et al., 2009). Opioid peptides may thereby influence feed intake by mediating hedonism and incentive motivation upon feed consumption (LeMagnen, 1990; Berridge, 2009), and it has been suggested that blocking their activity may render palatable feeds less rewarding (Drewnowski et al., 1992; Giraudo et al., 1993). Naloxone is an opioid receptor antagonist and its peripheral administration reduces DMI in ruminants (Cheema et al., 1991; Obese et al., 
2007). Moreover, naloxone injection increased blood insulin concentrations in heifers (Burgwald-Balstad et al., 1995), suggesting that an interaction may exist among opioid antagonist administration and other anorexigenic metabolites related to energy balance, such as insulin, cholecystokinin, and glucagon-like peptide-1.

Our hypothesis was that blocking opioid receptors might blunt oro-sensorial preferences of calves, thereby decreasing the rewarding response associated with feed intake. Furthermore, we expected that the effects of blocking opioid receptors would depend on circulating insulin and anorexigenic hormones as dictated by the metabolic status of the calves. Thus, the objectives of the current study were to determine if naloxone would (1) decrease feed intake by modifying oro-sensorial preferences for a sweet feed; and (2) affect plasma glucose, insulin, cholecystokinin, and glucagon-like peptide-1 concentrations in fasted or fed calves.

\section{MATERIALS AND METHODS}

\section{Animals, Feeding, and Management}

Thirty-two male Holstein calves participated in this study. All calves were purchased from commercial farms and raised in the facilities of the Institute for Research and Technology in Agrifood (IRTA, Caldes de Montbui, Spain). Calves were housed in individual hutches $(1 \times$ $1.55 \mathrm{~m}$ ) and managed under the guidelines and approval of the Animal Care Committee of IRTA. Hutches were bedded with sawdust every $3 \mathrm{~d}$. All calves had access to 2 buckets, one containing solid feed and the other containing water. A commercial milk replacer $(25 \%$ CP and 19.2\% fat, Sprayfo Excellent 60, Sloten BV, Deventer, the Netherlands) was offered in 2-L bottles twice daily at 0700 and $1700 \mathrm{~h}$. Calves received $4 \mathrm{~L} / \mathrm{d}$ of milk replacer at $12.5 \% \mathrm{DM}$ dilution rate until 50 d of age. From 50 to 56 d of age, calves received only the morning feeding of $2 \mathrm{~L}$ of milk replacer at $12.5 \%$ DM. Animals were weaned at $57 \mathrm{~d}$ of age. Starter feed (Table 1) and water were offered ad libitum throughout the study.

\section{Experiment 1: Preference for a Sweetened Starter Feed}

The aim of this experiment was to verify the establishment of a preference for a sweetener (Luctarom SFS-R; Lucta S.A., Montornès del Vallès, Spain) in weaned calves at the age of 72,73 , and 74 d (i.e., 15 $\mathrm{d}$ after weaning). This experiment was performed in 2 periods, using 16 animals per period. During the experiment, all calves $(\mathrm{n}=32)$ received a choice in
2 separated buckets of a control feed (CF; Table 1) that had previously been consumed by all calves, and the same starter feed with the addition of a noncaloric sweetener (sweet feed, SF; CF $+1 \mathrm{~g} / \mathrm{kg}$ of Luctarom SFS-R). Calves were offered a known amount of fresh $\mathrm{CF}$ and $\mathrm{SF}$ in 2 separated buckets at $0800 \mathrm{~h}$, and feed consumption was recorded 2,4 , and $6 \mathrm{~h}$ after feeding. After $6 \mathrm{~h}$, the remaining feed was removed and fresh CF was offered separately in 2 buckets to all calves.

\section{Experiment 2: Control of Feed Intake and the Interaction Between Opioids and Metabolic State of Calves}

The aim of this experiment was to explore the potential interaction between opioid-mediated and metabolic (dictated by the fed state) control of feed preferences and intake. Similar to experiment 1, this experiment was conducted in 2 periods using half of the animals $(\mathrm{n}=16)$ in each period. Calves were weighed and randomly distributed according to $\mathrm{BW}$ and age in 4 groups, following a $2 \times 2$ factorial design. One day before the onset of the experiment, calves $(75 \pm 0.66 \mathrm{~d}$ of age) were fitted with jugular catheters (AbbocathT $16 \mathrm{G} \times 140 \mathrm{~mm}$; Hospira Inc., Lake Forest, IL) to facilitate blood sampling and administration of treatments. Catheter patency was maintained by flushing with $5 \mathrm{~mL}$ of heparinized saline solution (1,000 USP

Table 1. Ingredient and chemical composition of the experimental starter feed

\begin{tabular}{lc}
\hline Item & $\begin{array}{c}\text { Starter } \\
\text { feed }\end{array}$ \\
\hline Ingredient (\% of DM) & \\
Wheat & 20 \\
Corn & 15 \\
Barley & 11.2 \\
Sorghum & 12 \\
Soybean meal & 23 \\
Wheat middling & 12 \\
Soybean hulls & 5 \\
Premix & 0.2 \\
Calcium carbonate & 0.5 \\
Dicalcium phosphate & 0.3 \\
Sodium chloride & 0.8 \\
Nutrient (\% of DM) & \\
CP & 19.5 \\
NDF & 17.7 \\
ADF & 8 \\
Ash & 5.6 \\
\hline
\end{tabular}

${ }^{1}$ Contained vitamin A: 2,007,000 IU/kg; vitamin $\mathrm{D}_{3}: 433,000 \mathrm{IU} / \mathrm{kg}$; vitamin $\mathrm{E}: 3,685 \mathrm{mg} / \mathrm{kg}$; vitamin $\mathrm{B}_{1}: 52 \mathrm{mg} / \mathrm{kg}$; vitamin $\mathrm{B}_{2}: 197 \mathrm{mg} /$ $\mathrm{kg}$; vitamin $\mathrm{B}_{6}: 98 \mathrm{mg} / \mathrm{kg}$; vitamin $\mathrm{B}_{12}: 0.76 \mathrm{mg} / \mathrm{kg}$; vitamin $\mathrm{K}_{3}: 52$ $\mathrm{mg} / \mathrm{kg}$; nicotinic acid: $656 \mathrm{mg} / \mathrm{kg}$; pantothenic acid: $394 \mathrm{mg} / \mathrm{kg} ; \mathrm{Mn}$ : $5,877 \mathrm{mg} / \mathrm{kg}$; Fe: 7,093 mg/kg; Cu: 2,026 mg/kg; Co: $46 \mathrm{mg} / \mathrm{kg}$; Zn: $8,112 \mathrm{mg} / \mathrm{kg}$; I: $304 \mathrm{mg} / \mathrm{kg}$; Se: $46 \mathrm{mg} / \mathrm{kg}$. 
units of heparin $/ \mathrm{mL})$. Half of the calves $(\mathrm{n}=16 ; 8$ calves per period) were either fed ad libitum (FED) until 10 min before the onset of the experimental period or fasted (FAS; $\mathrm{n}=16 ; 8$ calves per period) for $14 \mathrm{~h}$ until feeding at 0800 . Within each of these groups, at feeding time $(0800 \mathrm{~h})$, half of the calves $(\mathrm{n}=8$; 4 per period) were injected i.v. with either $1 \mathrm{mg}$ of naloxone (NAL; Sigma-Aldrich Quimica S.A., Madrid, Spain) per kilogram of BW diluted in $6 \mathrm{~mL}$ of saline solution $(0.9 \% \mathrm{NaCl})$ or $6 \mathrm{~mL}$ of saline solution $(\mathbf{S A L})$. Doses for NAL were based on previous studies (Alavi et al., 1991; Obese et al., 2007). Therefore, treatments were FAS-NAL $(\mathrm{n}=8 ; 86.1 \pm 4.74 \mathrm{~kg}$ of BW and $76.5 \pm$ $1.18 \mathrm{~d}$ of age), FAS-SAL $(\mathrm{n}=8 ; 87.9 \pm 2.31 \mathrm{~kg}$ of BW and $76.5 \pm 0.68 \mathrm{~d}$ of age), FED-NAL $(\mathrm{n}=8 ; 86.1 \pm$ $3.36 \mathrm{~kg}$ of BW and $77.1 \pm 2.30 \mathrm{~d}$ of age) and FED-SAL $(\mathrm{n}=8 ; 85.6 \pm 4.16 \mathrm{~kg}$ of BW and $76.1 \pm 0.77 \mathrm{~d}$ of age $)$.

At $0800 \mathrm{~h}$, known amounts of fresh $\mathrm{CF}$ and SF were offered in 2 separate buckets to all calves. At the same time, NAL or SAL was injected, and feed consumption was monitored at 2, 4, and $6 \mathrm{~h}$ thereafter. Blood samples were harvested at $-10,20,180$, and 240 min relative to NAL or SAL administration and feed offer. Between blood samples, catheter patency was maintained by flushing with $1 \mathrm{~mL}$ of heparinized saline solution (1,000 USP units of heparin/mL). All blood samples were harvested in 4-mL tubes containing EDTA as an anticoagulant (BD Vacutainer spray-coated $\mathrm{K}_{2}$ EDTA tubes, Becton, Dickinson and Co., Franklin Lakes, NJ) and 4-mL tubes containing a glycolysis inhibitor (BD Vacutainer fluoride tubes). Samples were refrigerated at $4^{\circ} \mathrm{C}$ until centrifuged at $1,500 \times g$ at $4^{\circ} \mathrm{C}$ for $15 \mathrm{~min}$, and plasma and serum were decanted and stored at $-20^{\circ} \mathrm{C}$ until analyses of insulin, glucagon-like peptide- 1 (GLP-1), cholecystokinin (CCK), and glucose.

Concentrations of insulin, CCK-8, and GLP-1 were measured using RIA as described by Villalba et al. (2011). The intraassay CV averaged less than 3.1, 2.6, and $4.1 \%$ for insulin, CCK-8, and GLP-1 assays, respectively.

The kit used for CCK determination binds to CCK-8 sulfate and cross-reacts with CCK-33 sulfate. For GLP1 determination, the kit used was specific for total GLP-1 (1-37) and GLP-1 (7-37). Serum glucose was determined using a glucose RTU kit (bioMerieux S.A., Marcy l'Etoile, France) with an intra- and interassay of 1.4 and $1.7 \%$, respectively.

\section{Calculations and Statistical Analyses}

In both experiments, oro-sensorial preference for SF was measured as the cumulative consumption of SF expressed as a percentage of total feed consumed: consumption of SF/(consumption of SF + consumption of feed $\mathrm{CF})] \times 100$. To assess whether the relative consumption of SF (as a percentage of total intake) differed from $50 \%$ (i.e., lack of preference), a one-sample comparison $t$-test using SAS (SAS Institute Inc., Cary, NC) was performed. Oro-sensorial preference values over $50 \%$ were considered to indicate a preference toward $\mathrm{SF}$ over $\mathrm{CF}$.

In experiment 1 , cumulative $\mathrm{CF}$, cumulative $\mathrm{SF}$, and total cumulative starter feed consumption, and orosensorial preference for SF at each recorded time (2, 4 and $6 \mathrm{~h}$ ) were analyzed using the MIXED procedure (SAS Institute Inc.), treating time (h) as repeated measure. The 3 sampling days were analyzed separately. The model included time as a fixed effect, and animal and period as random effects. Data from cumulative $\mathrm{CF}$, SF, and total starter feed consumption were rootsquare transformed to achieve a normal distribution. Least squares means presented herein for cumulative total starter feed consumption correspond to nontransformed data, and SEM and $P$-values correspond to the results from the mixed-effects model using root-square transformed data.

In experiment 2, cumulative $\mathrm{CF}, \mathrm{SF}$, and total starter feed consumption, oro-sensorial preference for $\mathrm{SF}$, and blood metabolite data were analyzed using the MIXED procedure (SAS Institute Inc.), treating time as a repeated measure. The statistical model included the effect of blocking opioid activity (NAL or SAL), the effect of metabolic state (fasted or fed), the effect of time relative to feeding, and their 2- and 3-way interactions as fixed effects, and period and animal as random effects. Due to the lack of normality, data from CF, $\mathrm{SF}$, and total cumulative consumption were root-square transformed, and data from plasma metabolites were log-transformed. Least squares means presented herein for total cumulative consumption and metabolite concentrations correspond to nontransformed data, but SEM and $P$-values are results from the mixed-effects model using root-square or log-transformed data.

\section{RESULTS AND DISCUSSION}

\section{Experiment 1: Preference for a Sweetened Starter Feed}

Cumulative $\mathrm{CF}, \mathrm{SF}$, and total feed intake and orosensorial preferences for SF are presented in Table 2. The SF was preferred $(P<0.01)$ over the $\mathrm{CF}$ at all recorded times $(2,4$, and $6 \mathrm{~h}$ postfeeding) on each sampling day. These data agree with the notion that calves select for sweet-tasting feeds (Goatcher and Church, 1970; Hellekant et al., 1994; Nombekela and Murphy, 
Table 2. Daily cumulative consumption of control starter feed (CF), sweetened starter feed (SF), and total starter feed, and oro-sensorial preference for a SF [(cumulative consumption of SF/cumulative total feed consumption $) \times 100]$ during 3 consecutive days in experiment 1

\begin{tabular}{|c|c|c|c|c|c|}
\hline \multirow[b]{2}{*}{ Item } & \multicolumn{3}{|c|}{ Time after feed offer, $\mathrm{h}$} & \multirow[b]{2}{*}{$\mathrm{SEM}^{1}$} & \multirow[b]{2}{*}{$P$-value } \\
\hline & 2 & 4 & 6 & & \\
\hline \multicolumn{6}{|l|}{ Day 1} \\
\hline Cumulative CF intake (g) & $101.4^{\mathrm{a}}$ & $144.2^{\mathrm{b}}$ & $172.8^{\mathrm{c}}$ & 2.01 & $<0.01$ \\
\hline Cumulative SF intake (g) & $354.2^{\mathrm{a}}$ & $508.6^{\mathrm{b}}$ & $624.7^{\mathrm{c}}$ & 0.86 & $<0.01$ \\
\hline Total cumulative feed intake $(\mathrm{g})$ & $455.6^{\mathrm{a}}$ & $652.8^{\mathrm{b}}$ & $797.5^{\mathrm{c}}$ & 0.90 & $<0.01$ \\
\hline Oro-sensorial preference for SF $(\%)$ & $76.6^{*}$ & $79.1^{*}$ & $79.7^{*}$ & 4.66 & 0.39 \\
\hline \multicolumn{6}{|l|}{ Day 2} \\
\hline Cumulative CF intake (g) & $95.5^{\mathrm{a}}$ & $144.8^{\mathrm{b}}$ & $223.6^{\mathrm{c}}$ & 1.10 & $<0.01$ \\
\hline Cumulative SF intake (g) & $378.8^{\mathrm{a}}$ & $507.2^{\mathrm{b}}$ & $607.3^{\mathrm{c}}$ & 0.91 & $<0.01$ \\
\hline Total cumulative feed intake (g) & $474.2^{\mathrm{a}}$ & $652.0^{\mathrm{b}}$ & $830.9^{\mathrm{c}}$ & 0.91 & $<0.01$ \\
\hline Oro-sensorial preference for SF (\%) & $80.2^{\mathrm{a} *}$ & $79.5^{\mathrm{a} *}$ & $74.7^{\mathrm{b} *}$ & 2.19 & $<0.01$ \\
\hline \multicolumn{6}{|l|}{ Day 3} \\
\hline Cumulative CF intake (g) & $81.7^{\mathrm{a}}$ & $124.2^{\mathrm{b}}$ & $200.5^{\mathrm{c}}$ & 3.57 & $<0.01$ \\
\hline Cumulative SF intake (g) & $367.2^{\mathrm{a}}$ & $546.1^{\mathrm{b}}$ & $716.1^{\mathrm{c}}$ & 0.90 & $<0.01$ \\
\hline Total cumulative feed intake $(\mathrm{g})$ & $448.9^{\mathrm{a}}$ & $670.3^{\mathrm{b}}$ & $916.6^{\mathrm{c}}$ & 1.30 & $<0.01$ \\
\hline Oro-sensorial preference for SF (\%) & $84.3^{\mathrm{a} *}$ & $83.5^{\mathrm{a} *}$ & $79.2^{\mathrm{b} *}$ & 9.25 & 0.04 \\
\hline
\end{tabular}

1995) and support the use of SF to evaluate the interaction between opioid-mediated and metabolic control of intake in experiment 2. As expected, cumulative feed consumption progressively increased $(P<0.01)$ over time. Because cumulative feed consumption increased with time, it seems that no negative postingestive feedback on intake (Forbes and Kyriazakis, 1995; Provenza, 1995) was triggered by the added sweetener.

\section{Experiment 2: Control of Feed Intake and the Interaction Between Opioids and Metabolic State of Calves}

Cumulative $\mathrm{CF}, \mathrm{SF}$, and total feed intake and orosensorial preferences for SF are presented in Table 3. As expected, FAS calves consumed more $(P<0.05)$ feed $(684.1 \pm 1.18 \mathrm{~g})$ than FED calves $(515.2 \pm 1.18 \mathrm{~g})$ on average throughout the study, but NAL treatment tended $(P=0.08)$ to reduce cumulative starter feed consumption only in FED calves (Figure 1). In contrast to these results, other authors (Baile et al., 1981; Alavi et al., 1991; Burgwald-Balstad et al., 1995) have reported an inhibitory effect of naloxone on feed intake when administered to fasted animals. Previous studies have been conducted in heifers (Burgwald-Balstad et al., 1995) and sheep (Baile et al., 1981; Alavi et al., 1991); therefore, differences in age and species coupled with different fasting times could explain the described discrepancy among studies. It would be reasonable to expect that as hunger increases, metabolic signals gradually become more relevant in controlling feed intake, eventually overcoming the positive effects on intake elicited by oro-sensorial preferences. Indeed, in rodents, the sensitivity of the endocannabinoid system, which is involved in the generation of hedonic reactions along with the opioid system (Berridge et al., 2009), is modulated by appetite-controlling signals such as leptin, CCK, and ghrelin (Di Marzo and Matias, 2005). Assuming that similar mechanisms are operative in ruminants, fasting would also upregulate appetitestimulatory neurotransmitters, which could nullify the effects of NAL. On the other hand, SAL calves consumed more $(P<0.05)$ starter feed $(442.2 \pm 1.33$ g) than NAL calves $(319.4 \pm 1.33 \mathrm{~g}) 2 \mathrm{~h}$ after feeding. Similar to other studies (Baile et al., 1981; BurgwaldBalstad et al., 1995), the inhibitory effect of naloxone on feed intake was only observed during the first $2 \mathrm{~h}$ after feeding. Naloxone is a short-acting opiate antagonist with a half-life of about $40 \mathrm{~min}$ in rats (Tepperman et al., 1983) and $1 \mathrm{~h}$ in humans (Ngai et al., 1976). As reported herein, therefore, any potential effect of naloxone on feed intake would be expected to last for only a short time after its administration.

As for the cumulative consumption of $\mathrm{CF}$ and $\mathrm{SF}$, NAL calves consumed more $(P<0.05)$ CF $(381.0 \pm$ $1.73 \mathrm{~g})$ than SAL calves $(212.6 \pm 1.73 \mathrm{~g})$ by $6 \mathrm{~h}$ postfeeding. On the other hand, SAL calves consumed, on average, more $(P<0.05) \mathrm{SF}(439.6 \pm 1.37 \mathrm{~g})$ than NAL calves $(297.4 \pm 1.37 \mathrm{~g})$. Overall, calves receiving SAL had a greater $(P<0.05)$ preference for SF $(70.3 \pm$ 


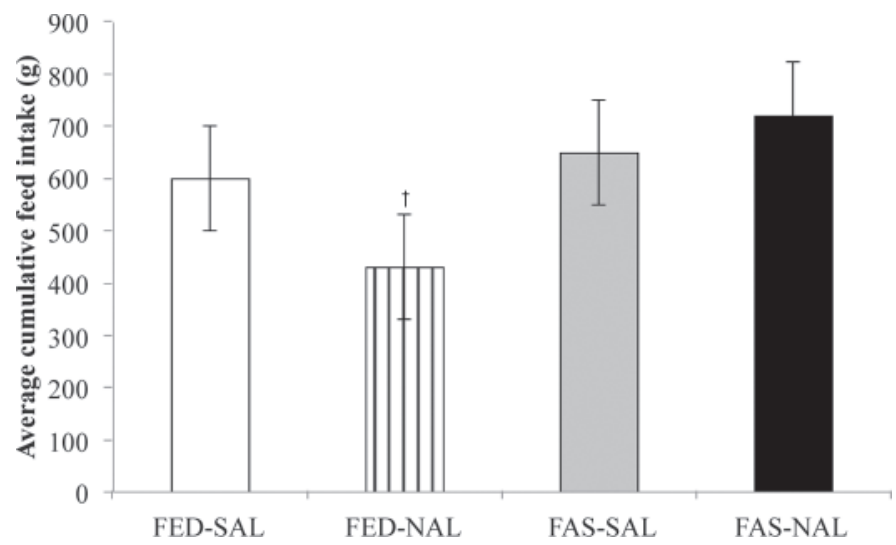

Figure 1. Average cumulative feed intake of well-fed calves that received $6 \mathrm{~mL}$ of saline solution $(0.9 \% \mathrm{NaCl}$; FED-SAL), well-fed calves that received $6 \mathrm{~mL}$ of naloxone $(1 \mathrm{mg} / \mathrm{kg}$ of $\mathrm{BW} ; \mathrm{FED}-\mathrm{NAL})$, calves fasted for $14 \mathrm{~h}$ and that received $6 \mathrm{~mL}$ of saline solution (FAS-SAL), and calves fasted for $14 \mathrm{~h}$ and that received $6 \mathrm{~mL}$ of naloxone (FASNAL). $†$ Average cumulative feed intake of FED-NAL calves tended to differ $(P<0.10)$ from that of the other groups. Error bars denote SEM.

$7.54 \%)$ than NAL calves $(51.9 \pm 7.54 \%)$, and FAS-SAL calves had a greater $(P<0.05)$ preference for SF $(73.5$ $\pm 8.32 \%)$ than FAS-NAL calves $(52.0 \pm 8.32 \%)$ at $6 \mathrm{~h}$ after feeding.

During the first $4 \mathrm{~h}$, FAS-SAL calves did not discriminate between starter feeds, although this group had a numerically greater preference for SF (Table 3). Forbes (2007) suggested that metabolic and physiological states could modify eating behavior. Furthermore, recent evidence from murine models indicate that opioids, endocannabinoids, and $\gamma$-aminobutyric acid (GABA)-benzodiazapines mediate hedonic responses to feed consumption by stimulating well-defined regions in the nucleus accumbens and ventral pallidum that have been jointly termed "hedonic hotspots" (Berridge et al., 2009). In rats, administration of an opioid-receptor agonist within those brain regions increases liking and eating behaviors triggered by sucrose, but the magnitude of such responses is influenced by several factors such as hunger, satiety, and taste preferences (Berridge, 2009; Berridge et al., 2009). Based on this notion, we hypothesize that in FAS calves, hunger diminished the sensitivity or activation of the opioid system and inhibited pleasure-dependent behaviors, ultimately minimizing the preference for SF during the first $4 \mathrm{~h}$ of the experiment. Interestingly, $6 \mathrm{~h}$ after feeding, FAS-SAL calves preferred $(P<0.05) \mathrm{SF}$ over $\mathrm{CF}$, whereas FASNAL continued to show no preference for SF (Table 3). On the other hand, FED-NAL calves did not discriminate between the 2 starter feeds during the first $4 \mathrm{~h}$ of experiment, and only tended $(P=0.07)$ to prefer $\mathrm{SF}$ $6 \mathrm{~h}$ after feeding (Table 3 ). These results indicate that

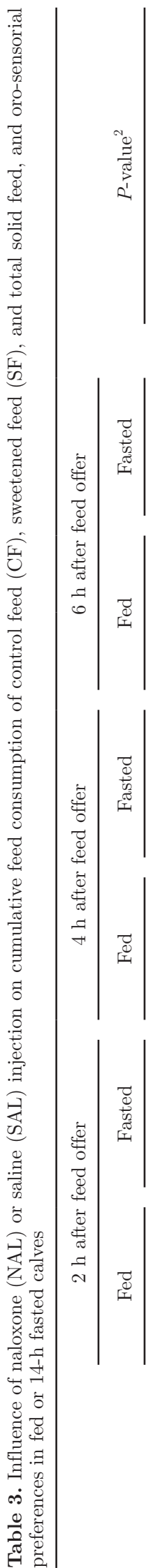

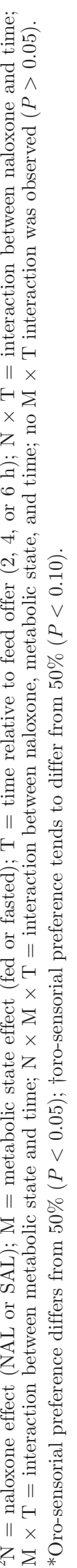


the influence of opioids on oro-sensorial preferences was more pronounced and lasted longer than their effect on the control of total feed consumption (which disappeared $2 \mathrm{~h}$ posttreatment). In humans, it has been reported that blocking opioid receptors decreases the degree of pleasantness elicited by consumption of certain foods, including sweet solutions (Fantino et al., 1986; Bertino et al., 1991; Yeomans and Wright, 1991; Drewnowski et al., 1992). In rats, opioid antagonists are most effective in reducing intake of palatable sweet liquids such as glucose, sucrose, or saccharin solutions (Holtzman, 1975; Lynch and Libby, 1983; Kirkham and Cooper, 1988; Morabia et al., 1989). Based on data in other species demonstrating that opioid receptors moderate effects on feeding, our results therefore suggest that naloxone inhibited the sensorial pleasure elicited by feed consumption, thereby contributing to control voluntary feed intake and voiding the preference for sweetened feeds.

Serum glucose and plasma insulin concentrations did not differ with sampling time (Table 4). As expected, FED calves had greater $(P<0.05)$ mean serum glucose $(4.08 \mathrm{mM})$ and plasma insulin $(121.5 \mathrm{pM})$ concentrations than FAS calves $(3.80 \mathrm{~m} M$ and $84.0 \mathrm{p} M$, respectively). Similar to the present study, fasting reduced concentration of glucose and insulin in the plasma of calves and sheep (Trenkle, 1976; Cole and Hallford, 1994). In the current study, calves were fasted for $14 \mathrm{~h}$, and FAS calves had greater starter feed consumption during the first $4 \mathrm{~h}$ after feeding compared with FED calves. However, serum glucose and plasma insulin concentrations continued to be greater for FED compared with FAS calves. Withholding feed has been shown to increase the hepatic removal of insulin (Brockman and Bergman, 1975), reduce secretion of insulin by isolated pancreatic tissues (Boden et al., 1981), diminish in vivo insulin secretion rate, and reduce postprandial insulin concentration (Trenkle, 1971). Serum glucose and plasma insulin concentrations did not differ between NAL and SAL calves. In rats, endorphins are capable of affecting circulating insulin and glucose directly via peripheral opiate receptors and (or) indirectly via opiate receptors located in the central nervous system (Appel et al., 1987; Curry et al., 1987). In agreement with our findings, however, no changes in serum glucose or plasma insulin concentration were observed when sheep were injected with naloxone (Alavi et al., 1991; Cheema et al., 1991).

Overall, FED calves had greater $(P<0.05)$ plasma CCK concentration than FAS calves (6.79 and $4.41 \mathrm{pM}$, respectively). The presence of fat and protein in the duodenum stimulates CCK secretion by endocrine cells of the upper small intestine (Liddle et al., 1985). Cholecystokinin acts on the hypothalamus as a neuropeptide

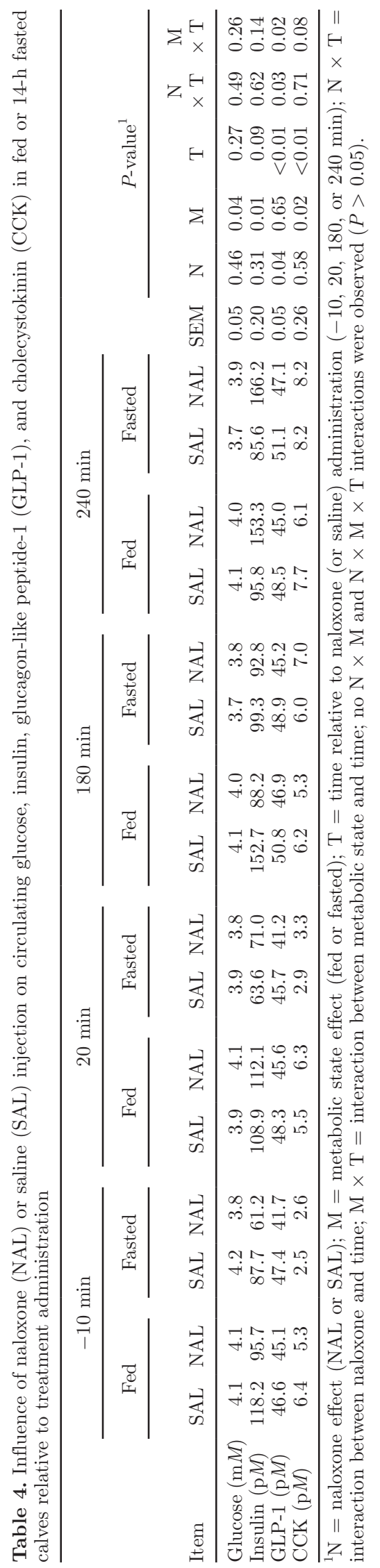


decreasing intake (Della Fera and Baile, 1979; Grovum, 1981). Plasma CCK concentration (Figure 2) tended to be greater $(P=0.08)$ in FED calves than in FAS calves at -10 (5.86 vs. $2.49 \mathrm{p} M$, respectively) and 20 $\min (6.16$ vs. $3.05 \mathrm{p} M$, respectively) relative to feeding time. Considering only plasma CCK concentration at -10 min relative to feeding time, FED calves had a greater $(P<0.05)$ concentration than FAS calves. However, plasma CCK concentration did not differ between NAL and SAL calves. As a result of the $14 \mathrm{~h}$ of fasting, the content of nutrients in the intestine of FED calves might have exceeded that of FAS calves (particularly during the first 2 sampling times), which could have led to a greater plasma CCK concentration in the former group of calves. In agreement with our results, Suominen et al. (1998) reported that plasma CCK concentration decreased during feed deprivation in heifers. However, in the current study, the lack of an effect of NAL on plasma CCK-8 concentration does not rule out an effect on other CCK forms secreted in ruminants that could affect the hypothalamus.

The metabolic state of calves had no effect on plasma GLP-1 concentration. Glucagon-like peptide-1 is secreted in response to feed consumption but it has an exceptionally short half-life of less than 2 min (Scheen, 2007). In the present study, blood was harvested 20 min after the feed was offered, and thus no differences in GLP-1 between FED and FASTED calves were expected. However, NAL calves had lower $(P<0.05)$ GLP-1 concentration (Figure 3) compared with SAL calves at 20 (42.8 vs. 47.9 p $M$, respectively) and $240 \mathrm{~min}$ (45.7 vs. $50.3 \mathrm{p} M$, respectively) after feeding. Recent studies with rodents provide the first demonstration that the gastrointestinal mucosa expresses taste signaling ele-

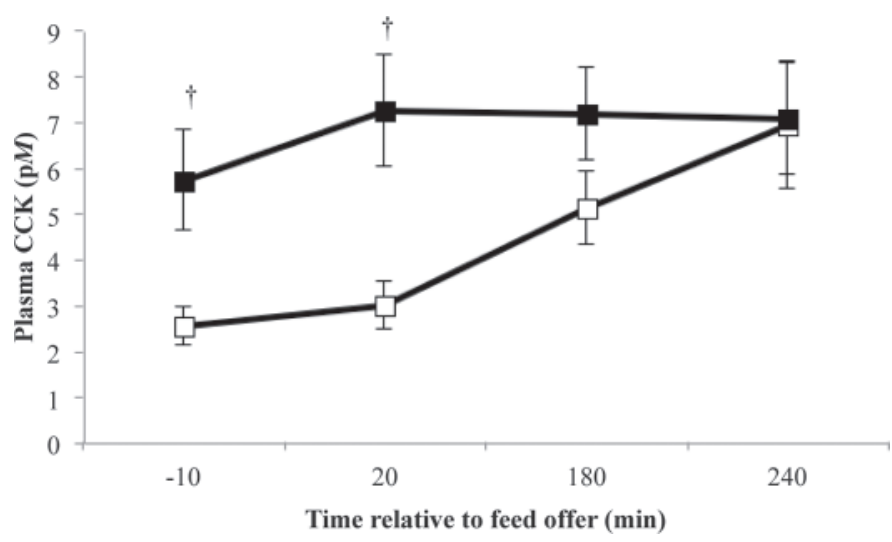

Figure 2. Plasma cholecystokinin (CCK) concentration (mean \pm SEM) at $-10,20,180$ and 240 min relative to feed offer in fed (ם) or 14-h fasted $(\square)$ calves. $†$ Plasma CCK concentration in fed and fasted calves tended to differ $(P<0.10)$.

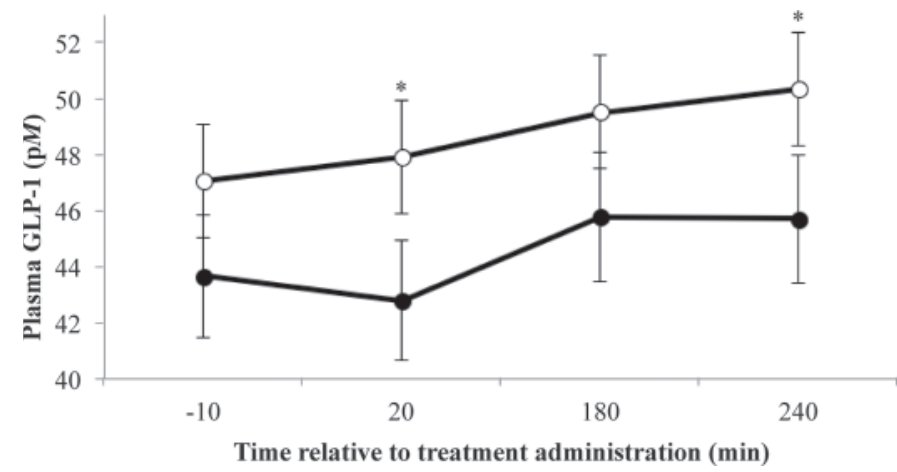

Figure 3. Plasma glucagon-like peptide-1 (GLP-1) concentration (mean \pm SEM) at $-10,20,180$ and 240 min in calves treated with a saline solution $(\bigcirc)$ or with naloxone $(\bullet)$. *Plasma GLP-1 concentration in calves treated with saline solution or naloxone differed at $P<$ 0.05 .

ments, such as the sweet taste receptor T1R2/T1R3, that form part of a chemosensing system by which luminal nutrients (e.g., glucose) and other nonnutritive chemicals (e.g., sweeteners) trigger physiological responses, including secretion of incretin hormones such as GLP-1 (Jang et al., 2007). In the current study, SAL calves had similar starter feed intake but a greater $(P<0.05)$ preference for SF than NAL calves $(70.3$ vs. $51.9 \%$, respectively). Therefore, it would seem reasonable to speculate that the intestinal mucosa of calves also has a chemosensing system that mediated changes in circulating GLP-1 in response to the larger intake of SF (sweetener) by SAL compared with NAL calves.

\section{CONCLUSIONS}

Injecting calves with naloxone alters short-term (2 h) feed intake. Furthermore, naloxone injection prevents calves from discerning between a sweetened and a plain starter feed, suggesting that in calves, as in other species, the opioid system controls short-term feed intake by modulating the oro-sensorial response to feed consumption. Blocking the opioid receptors with naloxone had no effect on the concentration of glucose, insulin and cholecystokinin, but did reduce the plasma GLP-1 concentration. Whether the changes in GLP-1 are mediated directly by naloxone or indirectly by the reduced consumption of sweetened starter remains to be elucidated.

\section{ACKNOWLEDGMENTS}

The authors thank the Spanish National Institute for Agriculture and Food Research and Technology (INIA, Madrid, Spain) for the fellowship that supported the work of Carlos Montoro. The authors gratefully ac- 
knowledge the technical assistance of E. Rodríguez, G. Araujo, Ll. Castells, M. Devant, M. Terré, and S. Martí from IRTA (Caldes de Montbui, Spain), and C. Colom, A. Mereu, and G. Tedó from Lucta (Montornès del Vallès, Spain).

\section{REFERENCES}

Alavi, F. K., J. P. McCann, S. Saniah, and A. Mauromoustakos. 1991. Effects of naloxone on ad libitum intake and plasma insulin, glucose and free fatty acids in maintenance fed sheep. Domest. Anim. Endocrinol. 8:109-115.

Appel, N. M., N. S. Track, and G. R. Van-Loon. 1987. Autonomic and endocrine participation in opioid peptide-induced hyperglycemia. J. Auton. Nerv. Syst. 20:221-231.

Bach, A. Optimizing performance of the offspring: Nourishing and managing the dam and post-natal calf for optimal lactation, reproduction, and immunity. J. Anim. Sci. http://dx.doi.org/10.2527/ jas.2011-4516. In press.

Baile, C. A., D. A. Keim, M. A. Della-Fera, and C. L. McLaughlin. 1981. Opiate antagonist and agonist and feeding in sheep. Physiol. Behav. 26:1019-1023.

Berridge, K. C. 2009. 'Liking' and 'wanting' food rewards: Brain substrates and roles in eating disorders. Physiol. Behav. 97:537-550.

Berridge, K. C., T. E. Robinson, and J. W. Alridge. 2009. Dissecting components of reward: 'Liking', 'wanting', and learning. Curr. Opin. Pharmacol. 9:65-73.

Bertino, M., G. K. Beauchamp, and K. Egelman. 1991. Naltrexone, an opioid blocker, alters taste perception and nutrient intake in humans. Am. J. Physiol. 261:R59-R63.

Boden, G., C. A. Baile, C. L. McLaughlin, and F. M. Matschinsky. 1981. Effects of starvation and obesity on somatostatin, insulin, and glucagon release from an isolated perfused organ system. Am. J. Physiol. 241:E215-E220.

Brockman, R. P., and E. N. Bergman. 1975. Quantitative aspects of insulin secretion and its hepatic and renal removal in sheep. Am. J. Physiol. 229:1338-1343.

Burgwald-Balstad, L. A., J. S. Caton, V. I. Burke, and K. C. Olson. 1995. Influence of forage level and naloxone injection on feed intake, digestion, and plasma hormone and metabolite concentrations in dairy heifers. J. Anim. Sci. 73:2677-2686.

Castells, L., A. Bach, G. Araujo, C. Montoro, and M. Terré. 2012. Effect of different forage sources on performance and feeding behavior of Holstein calves. J. Dairy Sci. 95:286-293.

Cheema, A. U., M. L. Galyean, J. S. Caton, and A. S. Freeman. 1991 Influence of protein levels and naloxone on ruminal fermentation, serum hormones and metabolites in lamb fed oat hay or barley straw. Small Rumin. Res. 5:47-55.

Clarke, I. J. 2001. Sex and season are major determinants of voluntary food intake in sheep. Reprod. Fertil. Dev. 13:577-582.

Cole, N. A., and D. M. Hallford. 1994. Influence of propionate load in fed or unfed lambs on blood metabolites and hormone patterns. J. Anim. Sci. 72:2141-2148.

Curry, D. L., L. L. Bennet, and L. C. Hao. 1987. Stimulation of insulin secretion by beta-endorphins (1-27 and 1-31). Life Sci. 40:20532058.

Della Fera, M. A., and C. A. Baile. 1979. CCK-octapeptide injected in CSF causes satiety in sheep. Ann. Rech. Vet. 10:234-236.

Di Marzo, V., and I. Matias. 2005. Endocannabinoid control of food intake and energy balance. Nat. Neurosci. 8:585-589.

Drewnowski, A., D. D. Krahn, A. Demitrack, K. Nairn, and B. A Gosnell. 1992. Taste responses and preferences for sweet high-fat foods: Evidence for opioid involvement. Physiol. Behav. 51:371379 .

Fantino, M., J. Hosotte, and M. Apfelbaum. 1986. An opioid antagonist, naltrexone, reduces preferences for sucrose in humans. Am. J. Physiol. 251:R91-R96.
Forbes, J. M. 2007. Voluntary Food Intake and Diet Selection in Farm Animals. CAB Int., Wallingford, UK

Forbes, J. M., and I. Kyriazakis. 1995. Food preferences in farm animals: Why don't they always choose wisely? Proc. Nutr. Soc. $54: 429-440$.

Giraudo, S. Q., M. K. Grace, C. C. Welch, C. J. Billington, and A. S. Levine. 1993. Naloxone's anorectic effect is dependent upon the relative palatability of food. Pharmacol. Biochem. Behav. 46:917921.

Goatcher, W. D., and D. C. Church. 1970. Taste responses in ruminants. I. Reactions of sheep to sugars, saccharin, ethanol and salts. J. Anim. Sci. 30:777-783.

Grovum, W. L. 1981. Factors affecting the voluntary intake of food by sheep. 3. The effect of intravenous infusions of gastrin, cholecystokinin and secretin on motility of the reticulo-rumen and intake. Br. J. Nutr. 45:183-201.

Hellekant, G., C. Hård af Segerstad, and T. W. Roberts. 1994. Sweet taste in calf: III. Behavioral responses to sweeteners. Physiol. Behav. 56:555-562.

Hökfelt, T., R. Elde, O. Johansson, L. Terenius, and L. Stein. 1977. The distribution of enkephalin-immunoreactive cell bodies in rat central nervous system. Neurosci. Lett. 5:25-31.

Holtzman, S. G. 1975. Effects of narcotic antagonist on fluid intake in the rat. Life Sci. 16:1465-1470.

Jang, H.-J., Z. Kokrashvili, M. J. Theodorakis, O. D. Carlson, B.-J. Kim, J. Zhou, H. H. Kim, X. Xu, S. L. Chan, M. Juhaszova, M. Bernier, B. Mosinger, R. F. Margolskee, and J. M. Egan. 2007. Gut-expressed gustducin and taste receptors regulate secretion of glucagon-like peptide-1. Proc. Natl. Acad. Sci. USA 104:15069 15074. PubMed

Khan, M. A., H. J. Lee, W. S. Lee, H. S. Kim, S. B. Kim, K. S. Ki, J. K. Ha, H. G. Lee, and Y. J. Choi. 2007. Pre- and postweaning performance of Holstein female calves fed milk through step-down and conventional methods. J. Dairy Sci. 90:876-885.

Kirkham, T. C., and S. J. Cooper. 1988. Attenuation of sham feeding by naloxone is stereospecific: Evidence for opioid mediation of orosensory reward. Physiol. Behav. 43:845-847.

LeMagnen, J. A. 1990. A role for opiates in food reward and food addiction. Pages 241-252 in Taste, Experience and Feeding. E. D. Capaldi and T. L. Powley, ed. American Psychological Association, Washington, DC

Liddle, R. A., I. D. Goldfine, M. S. Rosen, R. A. Taplitz, and J. A. Williams. 1985. Cholecystokinin bioactivity in human plasma. Molecular forms, responses to feeding, and relationship to gallbladder contraction. J. Clin. Invest. 75:1144-1152.

Lynch, W. C., and L. Libby. 1983. Naloxone suppresses intake of highly preferred saccharin solutions in food deprived and sated rats. Life Sci. 33:1909-1914.

Morabia, A., J. Fabre, E. Chee, S. Zeger, E. Orsat, and A. Robert. 1989. Diet and opiate addiction: A quantitative assessment of the diet of non-institutionalized opiate addicts. Br. J. Addict. 84:173-180.

Ngai, S. H., B. A. Berkowitz, J. C. Yang, J. Hempstead, and S. Spector. 1976. Pharmacokinetics of naloxone in rats and in man: Basis for its potency and short duration of action. Anesthesiology 44:398-401.

Nombekela, S. W., and M. R. Murphy. 1995. Sucrose supplementation and feed of dairy cows in early lactation. J. Dairy Sci. 78:880-885.

Obese, F. Y., B. K. Whitlock, B. P. Steele, F. C. Buonomo, and J. L. Sartin. 2007. Long-term feed intake regulation in sheep is mediated by opioid receptors. J. Anim. Sci. 85:111-117.

Provenza, F. D. 1995. Postingestive feedback as an elementary determinant of food preference and intake in ruminants. J. Range Manage. 48:2-17.

Roth, B. A., N. M. Keil, L. Gygax, and E. Hillmann. 2009. Influence of weaning method on health status and rumen development in dairy calves. J. Dairy Sci. 92:645-656.

Sartin, J. L., B. K. Whitlock, and J. A. Daniel. 2011. Triennial growth symposium: Neural regulation of feed intake: Modification by hormones, fasting, and disease. J. Anim. Sci. 89:1991-2003. 
Scheen, A. J. 2007. Glucagon-like peptide-1 (GLP-1) new target for the treatment of type 2 diabetes. Rev. Med. Liege 62:217-221.

Suominen, A. H., D. R. Glimm, D. Tedesco, E. K. Okine, M. I. McBurney, and J. J. Kennelly. 1998. Intestinal nutrient-gene interaction: The effect of feed deprivation and refeeding on cholecystokinin and proglucagon gene expression. J. Anim. Sci. 76:3104-3113.

Tepperman, F. S., M. Hirst, and P. Smith. 1983. Brain and serum levels of naloxone following peripheral administration. Life Sci. 33:1091-1096.

Trenkle, A. 1971. Postprandial changes in insulin secretion rates in sheep. J. Nutr. 101:1099-1103.

Trenkle, A. 1976. Estimates of the kinetic parameters of growth hormone metabolism in fed and fasted calves and sheep. J. Anim. Sci. 43:1035-1043.
Villalba, J. J., A. Bach, and I. R. Ipharraguerre. 2011. Feeding behavior and performance of lambs are influenced by flavor diversity. J. Anim. Sci. 89:2571-2581.

Wagner, C. G., C. D. McMahon, D. L. Marks, J. A. Daniel, B. Steele, and J. L. Sartin. 2004. A role for agouti-related protein in appetite regulation in a species with continuous nutrient delivery. Neuroendocrinology 80:210-218.

Yeomans, M. R., and P. Wright. 1991. Lower pleasantness of palatable foods in nalmefene-treated human volunteers. Appetite 16:249259 . 